IRA-International Journal of Management \& Social Sciences

ISSN 2455-2267; Vol.03, Issue 03 (2016)

Institute of Research Advances

http://research-advances.org/index.php/RAJMSS

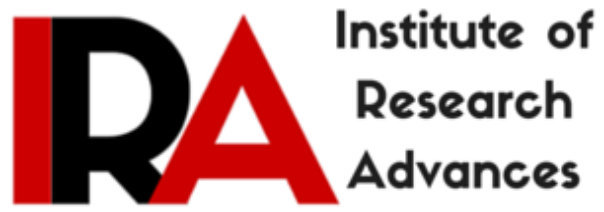

\title{
Socio Economic Factors of Contract Farming: A Logistic Analysis
}

\author{
Prof. A. P. Pandey
}

Professor \& Head, Department of Economics, Banaras Hindu University, Varanasi, U.P., India.

DOI: http://dx.doi.org/10.21013/jmss.v3.n3.p31

\section{How to cite this paper:}

Pandey, A. P. (2016). Socio Economic Factors of Contract Farming: A Logistic Analysis. IRA-International Journal of Management \& Social Sciences (ISSN 24552267), 3(3). doi:http://dx.doi.org/10.21013/jmss.v3.n3.p31

(C) Institute of Research Advances

\section{(cc) EY-NC}

This work is licensed under a Creative Commons Attribution-Non Commercial 4.0 International License subject to proper citation to the publication source of the work.

Disclaimer: The scholarly papers as reviewed and published by the Institute of Research Advances (IRA) are the views and opinions of their respective authors and are not the views or opinions of the IRA. The IRA disclaims of any harm or loss caused due to the published content to any party. 


\section{INTRODUCTION}

According to studies from Lajili et al. (1997), Rehber (2000), Sartwelle et al. (2000) and Key (2003), a farmer's discrete choice to join contract farming scheme or not it is influenced by the household's characteristics, operational features, socio-economic characteristics, market attributes of product and underlying agreement condition. Zhu found in a study of contract arrangement in China, that farmers' decisions to enter into contract with their sponsors were influenced by Economic influence, distance from the target market, specialization and commercialization of the production. In a study of contract farming in transitional economies of Eastern Europe, Swinnen (2005), found that the most important factors which is more influenced farmers to enter into contracts or not, in order of importance were; guaranteed product sales, avoidance of price uncertainty, higher price offers, profitability, pre-payment offer input supply and technical assistance and some form of credit.

In a detailed study of contract farming in poultry, chilly, Potato, banana, Wheat, Rice, maize, fruits and vegetables in Bali ,south Africa, India, America and Lombok province of Indonesia, it was revealed that factors that the important considerations and motivating factors for farmers were the increasing the productivity of crops, and getting better Income \& Price and less uncertainty; past experience in working with Contracting firm and agribusiness; education levels credit constraints and strong borrowing histories. The contracts were more appealing to less well-capitalization smallholders who were well educated, were credit constrained but who had strong borrowing histories (Patrick, 2004)*.

The main objective of this paper is to analyze the main socio-economic factors that motivate smallholder farmers to engage in contract farming mechanism or not.

\section{Methodology:-}

\section{Theoretical Framework - Motivation to Participate in Contract Farming Arrangement}

To analyze the socio-economic factors that influence farmer's decision to enter into contract agreements with processors, a logistical regression was used to determine the impact of those socio economic factors on farmers' decision to accept contract farming system or not. Farmers decision to participate in any production activity or not, are influenced in part by the perceived balanced of benefits, opportunities and constraints. Discrete choice models are used to identify and quantify the factors that affect the likelihood of a farmer participating in a production and/or marketing institutional arrangement. These models include the linear probability, Logit and Multinomial Logit models. This study opts for the logit model because the sample size is sufficiently large for normality to be assured.

\section{The logit model - Analytical model and Model specifications}

The study focuses on farmer's decision to adopt the farming method which is improve their farming pattern by providing better income and employment, farmers decision depends upon economic and social viability of the Contract farming system, it further quantifies the probability of the factors that may significantly constraint or influence the decision to adopt the contract farming method.

The logistic model is the standard method of analysis when the outcome variable is dichotomous ${ }^{\dagger}$ ( Hosmer and Lemeshow, 20evelop0), and the dependent variable was dichotomized with the value of 1 if the farmer's decision to accept the contract farming and 0 not accepting contract farming method. To assess the relative contribution of significant factor, binary logistic analyses was employed and predict a model with simple indicators was developed. This model predicts the probability that and individual with

\footnotetext{
${ }^{*}$ Patrick I. (2003). Contract farming in Indonesia: Smallholders and agribusiness working together.

${ }^{\dagger}$ Hosmer DW, Lemeshow S (2000).Applied Logistic Regression (Vol. 354 )
} 
certain socio-economic characteristic choose one of the alternative (Gujrati, 2003) cording to the logistic model, the probability, Pi, represent the adaptation behavior of the farmers of Uttar Pradesh.

$P i=\exp ^{Z i} / 1+\exp ^{Z i}$

Where $\mathrm{Pi}=\mathrm{a}$ random variable that predicts the probiability of the ith farmer is willing to participate in contract farming, $\mathrm{Zi}$ is an index that is linearly related to an array of socio-economic, demographic and other variables influencing farmers' willing to contract. More specifically, the relationship between these variables and $\mathrm{Zi}$ may be specified as follow:

$\mathrm{Zi}=\beta_{0}+\beta_{1} \mathrm{x}_{1 \mathrm{i}}+\beta_{2} \mathrm{x}_{2 \mathrm{i}}+\beta_{3} \mathrm{x}_{3 \mathrm{i}}+$

The model is specification for the study can therefore be summarized in equation:-

$\mathrm{Zi}=\beta_{0}+\beta_{1} \mathrm{x}_{1}+\beta_{2} \mathrm{x}_{2}+\beta_{3} \mathrm{x}_{3}$ $+\beta_{\mathrm{n}} \mathrm{x}_{\mathrm{n}}+\varepsilon$

\section{The Empirical Model}

Qualitative response models, which are strongly linked to utility theory, have been widely used in economics to investigate factors affecting an individual's choice from among two or more alternatives (Amemiya 1981; Greene, 2000). The model aims at determining the probability that, given a set of attributes about the individual farmer and other demographic characteristics, the individual will choose either to enter into contract or not.

Following the theoretical framework and the choice variables specified in studies by Lajili et al. ()1997), rehber (2000), Sartwelle et al. (2000) Zhu et al (2001), key (2003) and Gulati et al (2005), decision enter into contract farming arrangement in this study could be described as a function of personal characteristics of the farmer, household's characteristics, operation features, product categories, and market attributes $\$$. These factors have been decomposed in to the explanatory variables shown in the empirical model below. The model is specified as follow:

\section{$Y=\beta_{0}+\beta_{1}$ Gender $+\beta_{2}$ Education $+\beta_{3}$ Age $+\beta_{4}$ Family size $+\beta_{5}$ Loan $+\beta_{6}$ Electricity $+\beta_{7}$ Input $+\beta_{8}$ Off Farm $+\beta_{9}$ Less Uncertainty $+\beta_{9}$ Expected Price of Product $+\beta_{9}$ Employability $+\beta_{9}$ Nature of Farming $+\beta_{9}$ Earnings of Farmers...............(4)}

Here qualitative dependent variable is willing to adopt the contract farming or not, which takes on the value of 1 if the farmers adopted the contract farming method and 0 otherwise not adaptation occurred.

Where: $\mathrm{Y}=$ adaptation level $(1=$ adopters; $0=$ otherwise $)$ or proportion of farmers adopting the contract farming system for the particular value of the independent variable $\mathrm{X}_{1}, \mathrm{X}_{2}$, $X_{n}$ that influences

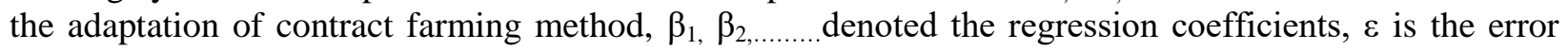
term.

\section{Statement of Hypothesis}

The following null hypotheses (Ho) were tested against the alternative (Ha).

The specific a priori expectations on the estimated parameters of equation (6) are:

(i) $\mathrm{H} 0: \beta_{1}-\beta_{9}=0$, Ha: $\beta_{1}-9>0$

\footnotetext{
${ }^{\ddagger}$ Key, N and D. Runsten., (1999). “Contract Farming, Smallholders, and Rural Development in Latin America:
} 
Where

H0: there is no effect of age on farmers' decision to participate in contract

Ha: there is a positive effect of age on farmers' decision to participate in contract.

H0: there is no effect of gender on farmers' decision to participant in contract farming

Ha: there is a positive effect of gender on farmers' decision to participate in contract.

The hypothesis is repeated similarly for

\section{Validation of Hypothesis:}

The $\mathrm{Z}$ statistic is used to measure the level of significance for each of the estimated coefficients. The goodness of fit statistic is the McFadden R-squared. The likelihood ratio (LR) test is computed to determine the joint significance of the independent variables in the model. The LR test follows a standard chi-square $\left(\chi^{2}\right)$ distribution the degrees of freedom to the number of independent variables used in the model. The higher the percentage prediction, the greater the predictive power of the model. The discussion of results is based on the log-odds ratio. The log-odds is given as

\section{$\beta \square[\log \mathbf{Y i} / 1$ - Yi $\square] / \square \beta \mathbf{X i} \equiv \partial M / \partial X i=\beta \mathbf{i}$}

\section{The marginal effects of the independent variables are also estimated. These are given as}

\section{$\partial Y i / \partial X i=\beta i[Y i(1-Y i)]$}

Where, Yi represents probabilities

\section{RESULTS AND DISCUSSIONS}

For a logistic regression, the predicted dependent variable is a function of the probability that a particular subject will be in one of the categories (for example, the probability that Suzie Cue has the disease, given her set of scores on the predictor variables).

\section{Reliability Analysis:-}

Cronbach's alpha reliability coefficient normally ranges between 0 and 1 . However, there is actually no lower limit to the coefficient. The closer Cronbach's alpha coefficient is to 1.0 the greater the internal consistency of the items in the scale. Based upon the formula ${ }_{-}=\mathrm{rk} /[1+(\mathrm{k}-1) \mathrm{r}]$ where $\mathrm{k}$ is the number of items considered and $\mathrm{r}$ is the mean of the inter-item correlations the size of alpha is determined by both the number of items in the scale and the mean inter-item correlations. George and Mallery ${ }^{\S}$ (2003) provide the following rules of thumb: “ $>.9$ - Excellent, ${ }_{-}>.8$ - Good, ${ }_{-}>.7$ - Acceptable, ${ }_{-}>.6-$ Questionable, $>>.5-$ Poor, and _ $<.5-$ Unacceptable" (p. 231). While increasing the value of alpha is partially dependent upon the number of items in the scale, it should be noted that this has diminishing returns. It should also be noted that an alpha of .8 is probably a reasonable goal. It should also be noted that while a high value for Cronbach's alpha indicates good internal consistency of the items in the scale, it does not mean that the scale is one-dimensional

Reliability Statistics
\begin{tabular}{|l|l|}
\hline $\begin{array}{l}\text { Cronbach's } \\
\text { Alpha }\end{array}$ & N of Items \\
\hline .917 & 16 \\
\hline
\end{tabular}

\footnotetext{
${ }^{\S}$ George, D., \& Mallery, P. (2003). SPSS for Windows step by step: A simple guide and reference. 11.0 update (4th ed.). Boston: Allyn \& Bacon
} 
This table represents the Reliability of the all variable which is 0.917 ; total numbers of items are sixteen. This value comes under the Excellence range that is greater than 0.9 .

Item-Total Statistics

\begin{tabular}{|c|c|c|c|c|}
\hline & $\begin{array}{l}\text { Scale Mean if } \\
\text { Item Deleted }\end{array}$ & $\begin{array}{l}\text { Scale Variance if } \\
\text { Item Deleted }\end{array}$ & $\begin{array}{l}\text { Corrected Item-Total } \\
\text { Correlation }\end{array}$ & $\begin{array}{l}\text { Cronbach's Alpha if } \\
\text { Item Deleted }\end{array}$ \\
\hline Types of the Farmers & 8.2125 & 23.952 & .792 & .906 \\
\hline $\begin{array}{l}\text { Decision about farming } \\
\text { System }\end{array}$ & 8.0400 & 26.334 & .317 & .920 \\
\hline Gender & 8.1125 & 25.895 & .391 & .918 \\
\hline Education & 8.1325 & 25.779 & .411 & .918 \\
\hline Age of The Farmers & 8.1400 & 25.750 & .416 & .917 \\
\hline Family Size & 8.2000 & 23.860 & .813 & .906 \\
\hline $\begin{array}{l}\text { Loan } \\
\text { Informal) }\end{array}$ (Formal \& & 8.1975 & 23.883 & .808 & .906 \\
\hline Using Electricity & 8.1875 & 24.158 & .748 & .908 \\
\hline Getting Input Timely & 8.1850 & 24.261 & .726 & .908 \\
\hline Off Farm Activity & 8.1775 & 24.888 & .592 & .912 \\
\hline $\begin{array}{lll}\text { Less } & \text { Uncertainty } & \text { of } \\
\text { Crops } & \end{array}$ & 8.1875 & 25.135 & .539 & .914 \\
\hline $\begin{array}{l}\text { Getting } \text { Better Crops } \\
\text { Prices }\end{array}$ & 8.1350 & 24.814 & .614 & .912 \\
\hline Good Employbility & 8.2000 & 25.178 & .529 & .914 \\
\hline Nature Of Farmers & 8.1575 & 24.524 & .672 & .910 \\
\hline $\mid \begin{array}{l}\text { Total Earning Is } \\
\text { Sufficient For Family }\end{array}$ & 8.2000 & 24.441 & .686 & .909 \\
\hline $\begin{array}{l}\text { All Children Go School } \\
\text { Regulerily }\end{array}$ & 8.2225 & 24.284 & .720 & .908 \\
\hline
\end{tabular}

The values in the column labelled Alpha if Item is Deleted are the values of the overall alpha if that item isn't included in the calculation. As such, they reflect the change in Cronbach's alpha that would be seen if a particular item were deleted. The overall alpha is .912, and so all values in this column should be around that same value. We're looking for values of alpha greater than the overall alpha because if the deletion of an item increases Cronbach's alpha then this means that the deletion of that item improves reliability. None of the items here would substantially affect reliability if they were deleted. 


\section{Decision about acceptance of contract farming by farmers}

Table 02

Decision about farming System * Types of the Farmers Cross tabulation

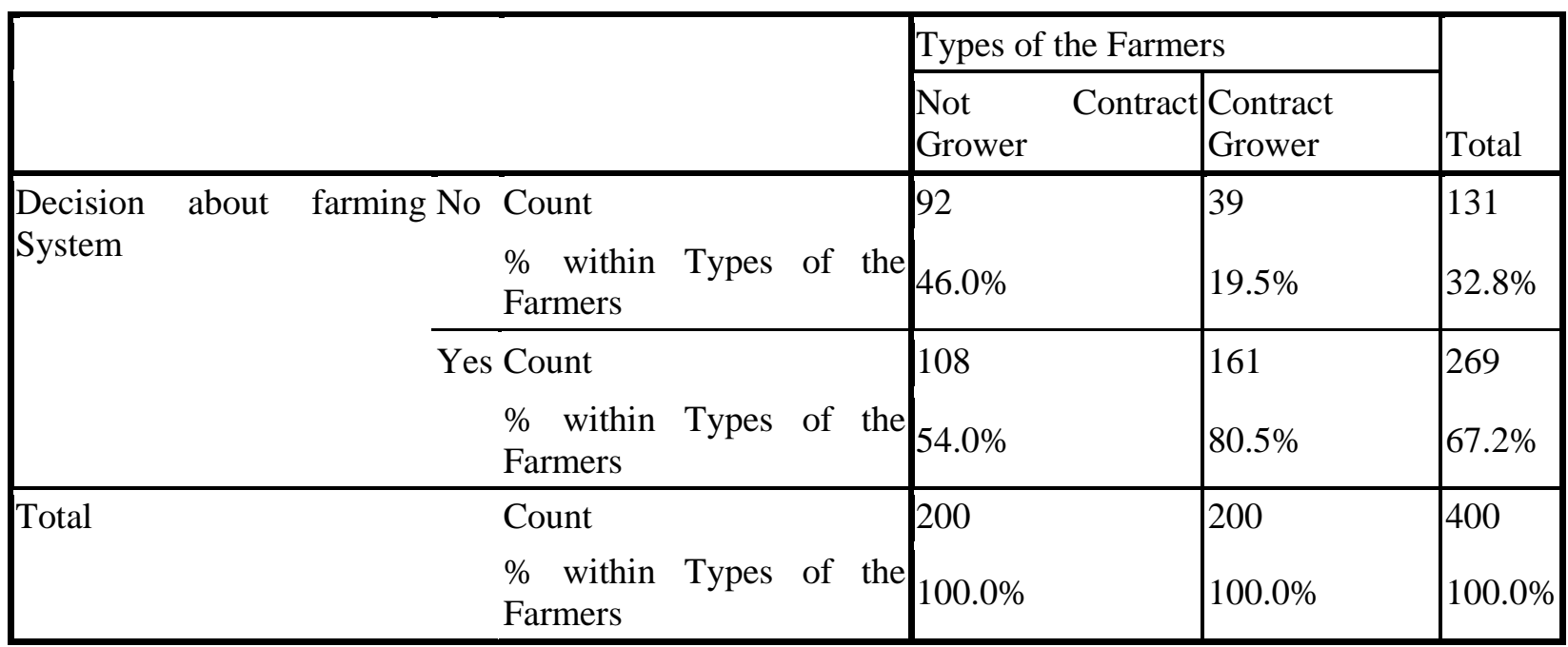

Table 02 shows the results obtained from the 200 non contract farmers and 200 contract farmers in the survey with respect to their decision to participate or otherwise in contract farming arrangement. The farmers who are already in the contract farming arrangement, their decision to participate in contract arrangement is $161(80.5 \%)$ When farmers with no contracts were asked if they were willing to engage in contract farming arrangements, an overwhelming 108 (54\%) responded in the affirmative.

Whereas the decision about not accepting the contract arrangement the answer of the contract growers are $39(19.5 \%) \&$ answer from non contract growers are 92 (46\%). Its decision represent enough difference $(46 \%-19.5 \%)=26.5 \%$ that is considerable.

The results suggest that most farmers tend to respond positively and have a strong desire to engage in contract arrangements if they were offered the opportunity. From the results it can be inferred that farmers in Uttar Pradesh generally have a positive or favourable attitude towards contract farming.

Table 03 Chi-Square Tests

\begin{tabular}{|c|c|c|c|c|c|}
\hline & Value & $\mathrm{df}$ & Asymp. Sig. (2-sided) & Exact Sig. (2-sided) & Exact Sig. (1-sided) \\
\hline Pearson Chi-Square & $31.885^{\mathrm{a}}$ & 1 & .000 & & \\
\hline Continuity Correction $^{\mathrm{b}}$ & 30.693 & 1 & .000 & & \\
\hline Likelihood Ratio & 32.581 & 1 & .000 & & \\
\hline Fisher's Exact Test & & & & .000 & .000 \\
\hline Linear-by-Linear Association & 31.805 & 1 & .000 & & \\
\hline $\mathrm{N}$ of Valid Cases ${ }^{\mathrm{b}}$ & 400 & & & & \\
\hline
\end{tabular}

a. 0 cells $(.0 \%)$ have expected count less than 5 . The minimum expected count is 65.50 .

b. Computed only for a $2 \times 2$ table

Finally, the table below provides the summary statistic info. The observed chi-square statistic is 31.851 , which is associated with a $0.00 \%$ risk of being good in rejecting the null hypothesis. This is no any risk, so we are able to accept the null. We therefore find support for the research hypothesis, and can conclude 
that contract and not contract growers' and their decision to acceptance farming system in study.

\section{Logit Model:- Decision about the farming system of Contract Growers'}

\section{Classification Table ${ }^{a, b}$}

\begin{tabular}{|c|c|c|c|c|}
\hline & \multirow[b]{3}{*}{ Observed } & \multicolumn{3}{|c|}{ Predicted } \\
\hline & & \multicolumn{2}{|c|}{$\begin{array}{l}\text { Decision about farming } \\
\text { System }\end{array}$} & \multirow{2}{*}{$\begin{array}{l}\text { Percentage } \\
\text { Correct }\end{array}$} \\
\hline & & No & Yes & \\
\hline \multirow[t]{3}{*}{ Step 0} & Decision about farming No & 0 & 39 & .0 \\
\hline & System & 0 & 161 & 100.0 \\
\hline & Overall Percentage & & & 80.5 \\
\hline
\end{tabular}

a. Constant is included in the model.

b. The cut value is .500

\section{Decision about the farming system of Non Contract Growers'}

Classification Table ${ }^{\mathbf{a}, \mathbf{b}}$
\begin{tabular}{|c|l|l|l|}
\hline \multirow{2}{*}{ Observed } & \multicolumn{2}{|l|}{ Predicted } \\
\cline { 2 - 4 } & \multicolumn{2}{|l|}{ Decision about farming System } & \multicolumn{1}{l|}{ Percentage Correct } \\
\cline { 2 - 4 } & No & Yes & .0 \\
Step 0 Decision about farming System No & 0 & 92 & 100.0 \\
Overall Percentage & & 108 & 54.0 \\
\hline
\end{tabular}

a. Constant is included in the model.

b. The cut value is .500

In the Table 01 (Contract Growers) the Block 0 output is for a model that includes only the intercept. Given the base rates of the two decision options $(39 / 200)=19.5 \%$ decided to not accept the contract farming system, $81.5 \%$ decided to continue working with contract farming system, and no other information, the best strategy is to predict, for every case, that the subject decided to work with contract farming system. Using this strategy, we would be correct $80 \%$ of the time.

And another side in the table $\mathbf{0 2}-46 \%$ of the non contract growers' decided to work with contract farming system $54 \%$ farmers want to work with contract farming system., that the subject decided to work with contract farming system. Using this strategy, we would be correct $54 \%$ of the time. By the comtrative analysis of the both tables we can say the percentage of working with contract farming system is high of Contract growers. 
Table 03 (CF)

Variables in the Equation

\begin{tabular}{|c|c|c|c|c|c|c|c|}
\hline & & B & S.E. & Wald & df & Sig. & $\operatorname{Exp}(B)$ \\
\hline Step 0 & Constant & 1.418 & .178 & 63.113 & 1 & .000 & 4.128 \\
\hline
\end{tabular}

Table 04 (NCF)

Variables in the Equation

\begin{tabular}{|c|c|c|c|c|c|c|c|}
\hline & & B & S.E. & Wald & df & Sig. & $\operatorname{Exp}(\mathrm{B})$ \\
\hline Step 0 & Constant & .160 & .142 & 1.277 & 1 & .258 & 1.174 \\
\hline
\end{tabular}

Under Variables in the Equation you see that the intercept-only model is $\ln$ (odds) $=\mathbf{1 . 4 1 8}$ for the contract growers (CG) and 0.160 for non-contract Growers (NCG). If we exponentiate both sides of this expression we find that our predicted odds $[\operatorname{Exp}(\mathrm{B})]=.4 .128$ for $(\mathrm{CG}) \& 1.174$ for $(\mathrm{NCG})$. That is, the predicted odds of deciding to work contract farming system for CG is 4.128 and for NCG is 1.174. This means contract growers want to work with contract farming system near about four times to the non contract growers.

Omnibus Tests of Model Coefficients gives us a Chi-Square of (CG) 25.555 and for (NCG) 16.491 on 1 $d f$, significant beyond .000 and 0.258 . This is a test of the null hypothesis that adding the size of farmer's variable to the model has not significantly increased our ability to predict the decisions made by our subjects.

(CG)Omnibus Tests of Model Coefficients

\begin{tabular}{|ll|l|l|l|}
\hline & & Chi-square & df & Sig. \\
\hline Step 1 & Step & 25.555 & 1 & .000 \\
& Block & 25.555 & 1 & .000 \\
& Model & 25.555 & 1 & .000 \\
\hline
\end{tabular}

(NCG)Omnibus Tests of Model Coefficients

\begin{tabular}{|ll|l|l|l|}
\hline & & Chi-square & df & Sig. \\
\hline Step 1 & Step & 16.491 & 1 & .000 \\
& Block & 16.491 & 1 & .000 \\
& Model & 16.491 & 1 & .000 \\
\hline
\end{tabular}

Under Model Summary we see that the -2 Log Likelihood statistics are $171.801 \& 259.487$. This statistic measures how poorly both the model predicts the decisions about farming system by small \& big farmers -- the smaller the statistic the better the model. After Adding the more variable as like gender, age of the farmers, and gender etc. variable reduced the -2 Log Likelihood statistics by $197.356-171.801=$ $25.555(\mathrm{CG}) \& 275.978-259.487=16.491(\mathrm{NCG})$, both model is very weak but model of contract growers is more weak then non-contract grower model so we add some another variables, The Cox \& Snell $R^{2}$ can be interpreted like $R^{2}$ in a multiple regression, but cannot reach a maximum value of 1 . The Nagelkerke $R^{2}$ can reach a maximum of 1 and in the both models its value is very low. 


\section{Model Summary (CG)}

\begin{tabular}{|c|c|c|c|}
\hline ep & $\mid \begin{array}{l}-2 \\
\text { likelihood }\end{array}$ & $\begin{array}{l}\text { Cox } \\
\text { Snell } \\
\text { Square }\end{array}$ & \begin{tabular}{l|l}
$\&$ & \\
$\mathrm{R}$ & Nagelkerke \\
$\mathrm{R}$ Square
\end{tabular} \\
\hline & $171.801^{\mathrm{a}}$ & .120 & .191 \\
\hline
\end{tabular}

a. Estimation terminated at iteration number 5 because parameter estimates changed by less than .001 .
Model Summary(NCG)

\begin{tabular}{|l|l|lr|l|}
\hline Step & $\begin{array}{l}-2 \quad \text { Log } \\
\text { likelihood }\end{array}$ & $\begin{array}{ll}\text { Cox } & \& \\
\text { Snell } & \text { R } \\
\text { Square }\end{array}$ & $\begin{array}{l}\text { Nagelkerke } \\
\text { R Square }\end{array}$ \\
\hline 1 & $259.487^{\mathrm{a}}$ & .079 & .106 \\
\hline
\end{tabular}

3 because parameter estimates changed by less than .001 .

The Variables in the Equation output shows us that the regression equation is

In $($ ODDS $)=-0.182+2.121$ (Size of Farmers) ..(CG)

Variables in the Equation

\begin{tabular}{|ll|l|l|l|l|l|l|l|l|l|}
\hline & & & & & & & \multicolumn{2}{|l|}{$95.0 \%$ C.I.for EXP(B) } \\
\cline { 8 - 10 } & & B & S.E. & Wald & df & Sig. & $\operatorname{Exp}(B)$ & Lower & Upper \\
\hline Step 1 & & Size of Farmers & 2.121 & .420 & 25.470 & 1 & .000 & 8.343 & 3.660 & 19.016 \\
& Constant & -.182 & .350 & .272 & 1 & .602 & .833 & & \\
\hline
\end{tabular}

a. Variable(s) entered on step 1: Size of the farmers.

We can now use this model to predict the odds that a subject of a given gender will decide to continue the research. The odds prediction equation is ODDS $=e^{a+b x}$

If our subject is size of Farmers Small and Big farmers (Big farmers $=0$ ), then the ODDS $=\mathbf{e}^{-\mathbf{0 . 1 8 2}+2.121}$ ${ }^{(0)}=\mathrm{e}^{-0.809}=\mathbf{0 . 4 4 9 3}$ That is, big farmers is only .4493 as likely to decide to continue work with contract farming system as They are to decide Not working the contract farming system.

\section{$\hat{\mathbf{Y}}=\mathbf{O D D S} / \mathbf{1}+$ ODDS}

\section{The validity of the model}

The coefficients of the binary logistic regression model were estimated by maximum likelihood methods. The Hosmer and Lemeshow statistic is one of the most reliable tests of model fit for binary regression (Sidibe', 2005). The results of the model are given in Table 3. The overall percentage of correct predictions is $93.5 \%$. The p-value 0.138 uses the Hosmer and Lemeshow Goodness-of-Fit Test, which is computed from the Chi-square distribution with 7 d.f. We fail to reject the null hypothesis that there is no difference between the observed and predicted values of the dependent, implying that the model's estimates very well fit the data at an acceptable level. Sidibe' (2005) also mentioned that a p-value less than 0.05 indicate a poor fit for a binary logistic regression model.

The column, exp (B), in Table 3 gives the exponential of expected value of B raised to the value of the logistic regression coefficient, which is the predicted change in odds for a unit increase in the corresponding explanatory variable. Table 3 showed that 12 explanatory variables in the model were 
significant (7 variables at the 1\%level, 1 at the 5\%level, and 4 at the 10\% level) in explaining RHSIT adoption behavior in the semiarid Loess Plateau of China. Expressed in terms of the variables used in this case, the logistic regression equation

Parameter estimated of binary logistic regression model for factor influencing adaptation of Contract Farming Arrangements by the Contract Growers of Uttar Pradesh

\begin{tabular}{|l|l|l|l|l|l|l|l|l|l|}
\hline & & & & & & \multicolumn{3}{l|}{$95.0 \%$ C.I.for EXP(B) } \\
\cline { 6 - 9 } & & B & S.E. & Wald & df & Sig. & Exp(B) & Lower & Upper \\
\hline Step $1^{\mathrm{a}}{ }^{2}$ & Gender & -1.759 & .853 & 4.254 & 1 & .039 & .172 & .032 & .916 \\
Education & 1.373 & .771 & 3.169 & 1 & .075 & 3.947 & .871 & 17.895 \\
Age & -.232 & .840 & .076 & 1 & .783 & .793 & .153 & 4.118 \\
Family size & -.948 & 1.422 & .444 & 1 & .505 & .388 & .024 & 6.290 \\
Loan & 2.717 & 1.549 & 3.076 & 1 & .079 & 15.138 & .727 & 315.312 \\
Electricity & 1.538 & 1.084 & 2.012 & 1 & .156 & 4.657 & .556 & 39.003 \\
Input & .183 & 1.051 & .030 & 1 & .862 & 1.201 & .153 & 9.417 \\
Off farm & .644 & .857 & .564 & 1 & .452 & 1.904 & .355 & 10.220 \\
Less UN & 1.987 & .717 & 7.683 & 1 & .006 & 7.293 & 1.789 & 29.723 \\
Expect Price & .861 & .794 & 1.176 & 1 & .278 & 2.365 & .499 & 11.215 \\
Employability & 1.035 & .728 & 2.019 & 1 & .155 & 2.814 & .675 & 11.723 \\
Size of farmer & .728 & .903 & .650 & 1 & .420 & 2.071 & .353 & 12.159 \\
Earning Suff. & -.059 & 1.009 & .003 & 1 & .953 & .943 & .131 & 6.809 \\
Going School & 1.908 & .897 & 4.521 & 1 & .033 & 6.738 & 1.161 & 39.104 \\
Constant & -5.651 & 1.255 & 20.289 & 1 & .000 & .004 & & \\
\hline
\end{tabular}

a. Variable(s) entered on step 1: Gender, Education, Age, Family size, Loan, Electricity, Input, Off farm, Less UN, Expect Price, Employability, Size of farmer, Earning Suff, Going School.

\section{Logistic Model Analysis Estimates}

The Result of the Logistic model Estimates for contract growers are presented in the table 00 the result indicate that the overall model estimate, $93.5 \%$ of the total variable in the sample was explained by the logistic regression model and all selected explanatory variables are relevant in the explaining the adaptation decision for the contract farming of the contract growers.

The Logistic model analysis from survey data showed that Gender, Education level of the farmers, Loaning, Using Electricity, Less Uncertainty about the Cropping, Employability of the farmers and all children are going to school regularly were significant at $1 \%$ and $10 \%$ level respectively. However Age of the farmers, family size, Availability of Inputs, off farm income Expected Price of their Produce, Size of Farmers, and Earning Sufficient were not influence the adaptation behavior of the contract growers significantly. Age of the farmers was not a significant factor as expected in the study area possibly because almost all the farmers interviewed they could not take all decision. And every working part of agriculture divided all the family member according to their capacity by this age is no matter for taking the decision about farming system. 
This study also founded that household size was not significantly related to contract farming decision. Even though family labour constitutes a bulk of the labour used in agriculture in Uttar Pradesh and it is not always available for farm operations. Most of the poor farmers' families who are often not adopter also tend to seek alternative employment in the neighboring estate farms.

Availability of the inputs was not significantly related to contract farming decision for contract growers. This is the major component of the contract farming system; with it they are also poor for purchasing the inputs. But this economy situated in plan land and land is very productive, absence of economic environment for investments big farmers or other people for their earning invested their money in purchasing of Tractor, tubwell, harvesters, shop for seeds, and provided the machines in fare, so the availability of Inputs is very much in the economy.

Off farm income and Expected price of the produce, of the farmers were not significantly related to contract farming decision for contract growers. They were engaged many another economic activity to earn some money. Contract farming system provided them better price of their produce.

Gender of the farmer was found significant and positive related to adaptations behavior of the contract growers under the contract farming arrangement. This suggested that men are more likely to engage in contract farming arrangement. Some studies argue that literacy level is more in men in the respect of female by this can be happened. Mostly decision maker will be men, this also reasons for see significance value of the gender in the decision to accept the contract farming system.

Education of the contract growers were found significant and positive related to adaptation behavior of the contract growers. Main causes of it the literacy level and labour mobility is high in men, they can go anywhere at any time for one or more agreement. And another side it not applies in women's because of females has not enough awareness about this system and some social boundaries which are also responsible for it.

Low Loaning, Using Electricity and Less Uncertainty were found significant and positive related to adaptation of recommended contract farming Arrangements, it can be observed that under the contract farming system they borrow low loans for the markets because of contract farming companies also provides all the inputs in advance. And their farming method based on technology then electricity is the important for farming and insurance of the crops and farmers provide the less uncertainty, and another side advance payment of the crop prices by the contract farming companies protects them from market failure. All of above variable generate the attraction about contract farming system between farmers and change the adaptation behavior of the farmers.

Employability and All children going to school regularity were found significant and positive related to adaptation of recommended contract farming Arrangements between the contract growers, employability is most important variable in the economy of Uttar Pradesh, most of the population is illiterate or have a little literacy with it they have not enough skill, so employability will be viable aspect of the contract farming system. The aspects of Employability have high recommendation to adopt the Contract farming System.

Education is Most powerful tools for development but the cast of education is very high, the farmers who works under the contract farming Arrangement their children going to school regularity because they are not facing the problem of Low income, getting late wage etc.

\subsubsection{Farming characteristics}

As hypothesized, the diversity of irrigated crops (CROP) is positively correlated with adoption of RHSIT and very significantly at the $1 \%$ level. The greater the diversity of crops a farm household grows, the higher the probability of RHSIT adoption. A 1-unit increase in a diversity of irrigated crops grown by a 
household, especially high-value crops, will result in a 6.98 times increase in the log-odds of adoption. Chianu and Tsujii (2004) also reported similar findings on inorganic fertilizer adoption in Nigeria. Leib et al. (2002) also indicated that producers were willing to pay for irrigation scheduling to insure the quality of high-value crops. This is because the benefit derived from the high-value irrigated crops can be enough to compensate for the costs involved, which include

\section{ODDS $=\beta_{0}+\beta_{1}$ Gender $+\beta_{2}$ Education $+\beta_{3}$ Age $+\beta_{4}$ Family size $+\beta_{5}$ Loan $+\beta_{6}$ Electricity $+\beta_{7}$ Input $+\beta_{8}$ off farm $+\beta_{9}$ Less UN $+\beta_{10}$ Expect Price $+\beta_{11}$ Employability $+\beta_{12}$ Nature Far $+\beta_{13}$ Earning Sufficient $+\beta_{14}$ Going School}

ODDS $=-15.627-1.759$ Gender +1.373 Education -0.232 Age -0.948 Family Size +2.717 Loan + 1.538 Electricity +0.183 Input +0.644 Off Farm +1.987 Less Un certainty +.861 Expected price + 1.035 Employability + 0.728 Nature of Farmers -0.59 Earning Sufficient +1.908 Going to School

$>\beta_{1}$ : the odds ratio $(\exp (-1.759)=0.172)$ can be interpreted as the odds a Farmer with male status will attend to attained the contract farming is 0.172 (decrease of $83 \%$ ) times the odds that a farmer of female status will.

$>\beta_{2}$ : the odds ratio $(\exp (1.373)=3.947)$ can be interpreted as the odds a Farmer with educational status will attend to attained the contract farming is 3.947 (Increases of 394\%) times the odds that a farmer have no education status.

$>\beta_{3}$ : the odds ratio $(\exp (-0.232)=0.793)$ can be interpreted as the odds a Farmer with Young Age status will attend to contract farming is 0.793 (Decreases of $21 \%$ ) times the odds that a farmer have older age status.

$>\beta_{4}$ : the odds ratio $(\exp (-0.948)=1.422)$ can be interpreted as the odds a Farmer with big family status will attend to contract farming is 1.422 (Decreases of 142\%) times the odds that a farmer have small family status.

$>\beta_{5}$ : the odds ratio $(\exp (2.717)=15.138)$ can be interpreted as the odds a Farmer with no loan status will attend to contract farming is 15.138 (Increases of 1513\%) times the odds that a farmer have agricultural loan status.

$>\beta_{6}$ : the odds ratio $(\exp (1.538)=4.657)$ can be interpreted as the odds a Farmer with using the electricity will attend to contract farming is 4.657 (increases of $465 \%$ ) times the odds that a farmer have Electricity status.

$>\beta_{7}$ : the odds ratio $(\exp (0.183)=1.201)$ can be interpreted as the odds a Farmer with using the input timely will attend to contract farming is 1.201 (increases of $120 \%$ ) times the odds that a farmer have no timely input availability status.

$>\beta_{8}$ : the odds ratio $(\exp (0.644)=1.904)$ can be interpreted as the odds a Farmer with off farm working activity will attend to contract farming is 1.904 (increases of $190 \%$ ) times the odds that a farmer have no off farm working activity.

$>\beta_{9}$ : the odds ratio $(\exp (1.987)=7.293)$ can be interpreted as the odds a Farmer with Less Uncertainty will attend to contract farming is 7.293 (increases of $729 \%$ ) times the odds that a farmer have Uncertainty.

$>\beta_{10}$ : the odds ratio $(\exp (.861)=2.365)$ can be interpreted as the odds a Farmer getting excepted price will attend to contract farming is 2.365 (increases of $236 \%$ ) times the odds that a farmer have not getting excepted price status will.

$>\beta_{11}$ : the odds ratio $(\exp (1.035)=2.814)$ can be interpreted as the odds a Farmer have Employability will attend to contract farming is 2.814 (increases of $281 \%$ ) times the odds that a farmer have Unemployment status will.

$>\beta_{12}$ : the odds ratio $(\exp (.728)=2.071)$ can be interpreted as the odds a Farmer known as a small farmer will attend to contract farming is 2.071 (increases of $207 \%$ ) times the odds that a farmer known as a big farmer status will. 
$>\beta_{13}$ : the odds ratio $(\exp (-.059)=.943)$ can be interpreted as the odds a Farmer have sufficient Earning will attend to contract farming is .943 (decreases of $7 \%$ ) times the odds that a farmer not getting sufficient Earning status will.

$>\beta_{14}$ : the odds ratio $(\exp (1.908)=6.738)$ can be interpreted as the odds a Farmer's families children going to school will attend to contract farming is 6.738 (Increases of $673 \%$ ) times the odds that a Farmer's families children going to school status will.

A review of the table also indicates several other static tests. In the both of the coefficient to see if they are equal to zero with wald chi square test. We can see that all of the coefficients are significantly different from Zero.

\section{Farmer's perception}

As hypothesized, a farmer's positive attitude towards respect to adaptation of contract farming has a significant impact on the probability of adoption. Exp (B) shows that the odds of a farmer who has a positive attitude adopts contract farming is 8.4 times the odds of a farmer who has a negative attitude. The results imply that farmers' responsiveness to about the adaptation of contract farming depends heavily on the strength of this technology-related attitude. Somda et al. (2002) reported similar findings on compost adoption in Burkina Faso. The findings of some empirical studies show that farmers with a generally positive attitude are eager to adopt contract farming system. A household head's risk preference (RISK) is shown to significantly influence contract farming adoption decisions.

\section{References:-}

- Agresti, A. (1990); “Categorical Data Analysis” John Wiley \& Sons, Inc. New York, NY.

- Agresti, Alan (1996); “An introduction to categorical data analysis". NY: John wiley. An excellent, accessible introduction.

- Allison, P. D. (1999); "Logistic Regression Using the SAS System: Theory and Application" SAS Institute Inc., Cary, NC.

- Bishop, Y. M. M., Fienberg, S. E., and Holland, P. W. (1975); "Discrete Multivariate Analysis: Theory and Practice" The MIT Press, Cambridge, MA.

- Estrella, A. (1998); "A new measure of fit for equations with dichotomous dependent variables" Journal of Business and Economic Statistics 16(2): 198-205. Discusses proposed measures for an analogy to R2.

- Fox, John (2000); "Multiple and generalized nonparametric regression. Thousand Oaks, CA: Sage Publications. Quantitative Applications in the Social Sciences" Series No.131. Covers nonparametric regression models for GLM techniques like logistic regression. Nonparametric regression allows the logit of the dependent to be a nonlinear function of the logits of the independent variables.

- Garson, G.D., (2008); "Logistic Regression", from Statnotes: Topics in Multi-variate Analysis accessed at http://www2.chass.ncsu.edu/garson/pa765/statnote.htm.

- Hellin J, Dixon J, Higman S, Keleman A (2011); "Highvalue agricultural products and poverty reduction: Smallholder access to maize markets" Journal of Crop Improvement, 25: 371-391.

- Jaccard, James (2001); "Interaction effects in logistic regression" Thousand Oaks, CA: Sage Publications. Quantitative Applications in the Social Sciences Series, No. 135.

- Kontogeorgos , Achilleas. Sergaki, Panagiota. Migdakos, Euthimios. \& Semos, Anastasios. In their research paper, "Implementing Logistic Regression Analysis to Identify Incentives for Agricultural Cooperative Unions to adopt Quality Assurance Systems" (2008) International Conference on Applied Economics - ICOAE. 
- Lo, A.W. (1986); "Logit versus discriminant analysis: A specification test with applications to corporate bankruptcies"Journal of Econometrics 31:151- 178.

- Powers, D., and Y. Xie(2000); "Statistical method for categorical data analysis Academic Press." San Deigo, CA

- Peng, Chao-Ying Joann; Lee, Kuk Lida; \& Ingersoll, Gary M. (2002); “An introduction to logistic regression analysis and reporting” Journal of Educational Research 96(1): 3-13.

- Zugarramurdi, A., Parin A.M., Gadaleta, L., and Lupin, M.H., (2007), "A quality cost model for food processing plants", Journal of Food Engineering, 83:414-421. 